ÁREA ABIERTA. Vol. 14. № 2. Julio 2014

http://dx.doi.org/10.5209/rev_ARAB.2014.v35.n2.45766

"LA PINTURA SURREALISTA EN EL CINE DE ALMODÓVAR"

AUTOR: Carlos SALAS GONZÁLEZ.

Escuela de Arte de Murcia, España

\title{
La pintura surrealista en el cine de Almodóvar
}

\author{
The surrealistic painting \\ in Almodóvar's cinema
}




\title{
RESUMEN:
}

Almodóvar es uno de los cineastas más personales de las últimas décadas. Basta con ver un solo plano de cualquiera de sus películas para adivinar su autoría. En la configuración de tan particular universo juegan un importante papel las influencias de otras disciplinas artísticas, caso de la pintura. En ocasiones Almodóvar compone planos directamente inspirados en obras pictóricas, tanto del arte tradicional como, muy fundamentalmente, del contemporáneo. Explorar las referencias a la pintura surrealista existentes en su filmografía es el objetivo de este trabajo, para lo que se aplicarán criterios formalistas.

\section{Palabras clave:}

Almodóvar, cine, pintura, surrealismo

\begin{abstract}
:
Almodóvar is one of the most personal filmmakers of last last decades. It is enough to see a single shot of one of his movies to guess its authorship. In the configuration of such a particular universe the influences of other artistic disciplines play an important role, as in the case of painting. In some occasions Almodóvar composes scenes directly inspired by pictorial works, as much from traditional art as, and particularly, from the contemporary art. The purpose of this article is to explore the references to surrealistic painting in his films; to this end formalist criteria will be applied.
\end{abstract}

\section{Key words:}

Almodóvar, cinema, painting, surrealism 


\section{Almodóvar y la pintura}

La vinculación del cine de Almodóvar con la pintura puede observarse en distintos aspectos de sus películas. Entre ellos destacan los carteles publicitarios, los títulos de crédito, la incorporación de obras pictóricas como un elemento más de la escena o la propia composición de algunos planos.

En un certero trabajo sobre el importante papel que juega lo pictórico en los filmes del manchego, Navarrete-Galiano pone el acento en este último aspecto: "Crea nueva pintura, por un lado la recreación de cuadros conocidos, o por la conceptualización de lo que se conoce como tableaux vivants y por otra origina nuevas pinturas influidas por pintores (abstracción; realismo) por medio de la técnica o la sintaxis fílmica"2.

Resulta ésta, a buen seguro, la más sugerente relación con la pintura establecida por Almodóvar en sus películas. Y es precisamente en este ámbito donde se han encontrado numerosos referentes vinculados a algunos de los más destacados artistas del siglo XX, casi todos ellos pertenecientes al Pop-Art o a cualquiera de sus múltiples derivaciones, sobre todo a aquellas más vinculadas con lo kitsch, sin duda, un concepto estético íntimamente ligado al universo almodovariano. Una excepción en este sentido sería la del norteamericano Edward Hopper y la relación con algunos de sus más célebres lienzos que se adivina en ciertos planos de Mujeres al borde de un ataque de nervios (1988) 3 , así como en una escena concreta de La ley del deseo $(1987)^{4}$.

Es por ello que en el presente trabajo se haya apostado por analizar, entre las posibles influencias pictóricas que laten en los filmes de Almodóvar, aquellas que tienen su origen en un pasado más remoto, concretamente en un movimiento artístico de las viejas vanguardias como fue el surrealismo. Y es que, de hecho, el universo Almodóvar se puede calificar, entre otras muchas cosas, de surrealista ${ }^{5}$, por lo que tampoco nos ha de extrañar que precisamente el surrealismo ocupe un lugar de preferencia a la hora de surtir de referentes pictóricos a su cine ${ }^{6}$.

\footnotetext{
1 Sobre la presencia de lo pictórico en la obra de diferentes cineastas españoles véase CERRATO, Rafael. Cine y pintura, Ediciones JC, Madrid, 2010. Y HUESO MONTÓN, Ángel Luis. "Referentes pictóricos en el cine español" en VV. AA., Memoria Artis. Studia in Memoriam Ma Dolores Vila Jato. Tomo II, Xunta de Galicia, Santiago de Compostela, pp. 171-184.

2 NAVARRETE-GALIANO, Ramón. "Almodóvar; conceptualización de la pintura en los fotogramas", Razón y palabra, $n^{\circ} 74$, Noviembre 2010-Enero 2011.

3 lbídem.

4 Véase ALLINSON, Mark. Un laberinto español. Las películas de Pedro Almodóvar, Ocho y Medio, Madrid, 2003, p. 246.

5 En varias publicaciones se ha apuntado a las influencias del cine de Buñuel en Almodóvar. Un buen ejemplo se puede observar en FUENTES, Víctor, "Buñuel y Almodóvar: un discurso cinematográfico de las pasiones y el deseo" en VV.AA., ZURIÁN, Fran A., Y VÁZQUEZ VARELA, Carmen (Coords.). Almodóvar: el cine como pasión, Actas del Congreso Internacional "Pedro Almodóvar", Universidad de Castilla-La Mancha, 2005, pp. 93-106.

6 En la gran exposición sobre el cineasta celebrada en París en 2006, entre las variadas obras plásticas que formaron parte del montaje, hubo algunas pertenecientes a destacados artistas vinculados al surrealismo, entre los que se encontraban Joan Miró, Maruja Mallo o Jean Cocteau. Véase VV.AA. ¡Almodóvar Exhibition!. Les Éditions du Panama /La Cinématèque français, Paris, 2006.
} 


\section{Kubin}

Pocos mundos artísticos como el de Alfred Kubin guardan una relación tan estrecha con la estética desarrollada en los principales títulos del expresionismo cinematográfico. Dicho artista, originario de la región de Bohemia, destacó como ilustrador de obras literarias firmadas por algunos de los más sobresalientes escritores de su época, tales como Balzac, Kafka, E.T.A. Hoffman o Edgar Allan Poe ${ }^{7}$. En la mayor parte de estas obras, las ilustraciones llevadas a cabo por Kubin recrean un mundo fantástico y misterioso, lleno de sombras, habitado por criaturas monstruosas y los más variados fantasmas. No obstante, pese a que las temáticas tratadas en ellas son las mismas que poco después despertaron el interés de los cineastas alemanes, sus características plásticas, salvo algunas excepciones, suelen mantenerse lejos de aquellas que le son propias al expresionismo pictórico, teniendo poco que ver, por lo tanto, con el trazo grueso y anguloso que reina en los decorados de filmes como El gabinete del doctor Caligari (Das Kabinet des Dr. Caligari, 1919) ${ }^{8}$. Dicho lo cual, parecería que su relación con el expresionismo cinematográfico estribase más en cuestiones de carácter iconográfico que en otras relacionadas con criterios plásticos, pero su especial tratamiento de la luz y de la sombra nos dice otra cosa'. De hecho, la vinculación más directa que siempre se ha reconocido entre Kubin y el cine se halla en la forma de componer e iluminar algunos planos por parte de Friedrich W. Murnau, principalmente en dos de sus títulos más célebres: Nosferatu, el vampiro (Nosferatu, Eine Synphonie des Gravens, 1922) y Fausto (Faust, 1926).

Pero si vamos más allá de lo que supuso la ilustración de ciertos libros y ampliamos nuestra mirada al conjunto de su obra, coincidiremos en que Kubin parece estar en ocasiones mucho más cerca, ya no sólo en cuestiones formales y plásticas sino también iconográficas y temáticas, del simbolismo o del surrealismo -en este segundo caso, sería un claro precursor- que del expresionismo propiamente dicho. Obras como Salto mortal, La mujer, Lubricidad o La adoración, todas ellas realizadas entre 1901 y 1902, parecen buenos ejemplos. Y son precisamente obras de este tipo las que con más frecuencia han servido de inspiración a algunos cineastas de nuestro tiempo, siendo éste el caso de Almodóvar.

Dirigimos nuestro foco a una de las escenas más recordadas de Hable con ella (2002), notable película con la que el cineasta manchego logró el Óscar al mejor guion original. Un curioso cortometraje aparece inserto en la trama general del filme. Se trata de la proyección de una película muda a la que el protagonista, interpretado por Javier Cámara, asiste en el cine Doré, a la sazón sede de la Filmoteca Nacional. Su título es El amante menguante, lo que ya nos remite a un clásico de la ciencia-ficción, El increíble

\footnotetext{
7 El propio Kubin fue también escritor, destacando su novela distópica La otra parte (Die Andere Seite, 1909), considerada una de las joyas de la literatura fantástica centroeuropea.

8 Recordemos que su nombre, gracias al guionista Hans Janowitz, se barajó para ser el responsable de la escenografía de Caligari, sin embargo Wiene finalmente se inclinó por los artistas Hermann Warm, Walter Reimann y Walter Röhrig,

9 Véase BORAU, José Luis. La pintura en el cine; El cine en la pintura: discursos de ingreso en las RR.AA. de Bellas Artes de San Luis y San Fernando, con los de contestación correspondientes, Ocho y Medio, Madrid, 2003, p. 32.
} 
hombre menguante (The Incredible Shrinking Man, 1957), dirigida por Jack Arnold. Cuenta la disparatada historia de amor entre una bella joven y un científico cuyo cuerpo, tras un experimento fallido, queda alarmantemente menguado. Dicha secuencia transcurre en un laboratorio lleno de tubos y tarros en plena ebullición, siendo la película muda y estando rodada en blanco y negro, lo que nos trae a la memoria escenas similares de títulos señeros del cine de vanguardia alumbrado durante los años veinte ${ }^{10}$.

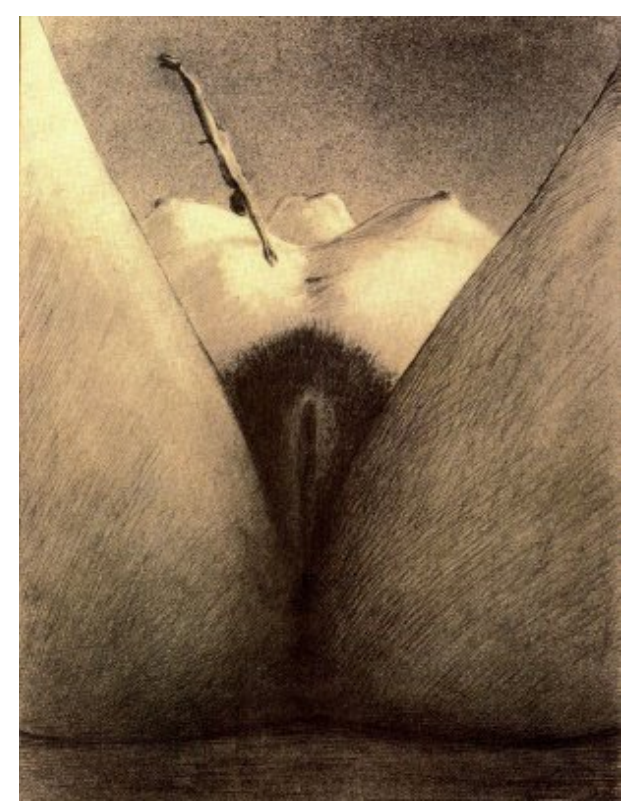

Salto mortal (A. Kubin, 1902)

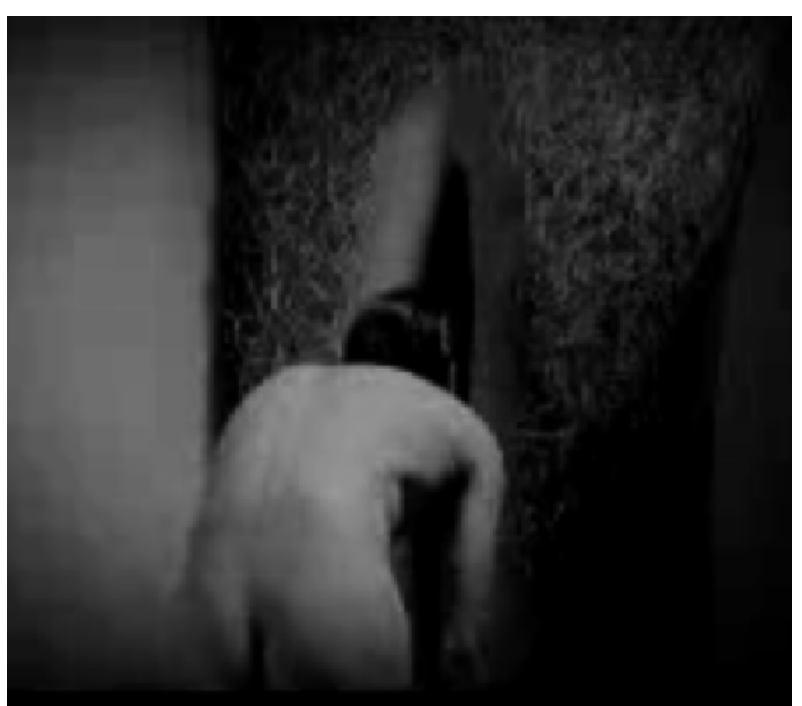

Hable con ella (P. Almodóvar, 2002)

Pero no son estos referentes cinéfilos los que aquí nos preocupan, sino una curiosa y directa referencia a las artes plásticas prevanguardistas. Y es que el clímax de esta deliciosa peliculita tiene lugar cuando el minúsculo científico se introduce, literalmente, en el cuerpo de su amada a través de la vagina". En palabras de Jean-Claude Seguin: "El Amante Menguante es un sueño de cuerpos -con su blanco y negro tan característico-, una escena de amor, la más densa imagen de la penetración"12. Desde luego, la imagen resulta tan sorprendente como original, pero quizá no se lo parezca tanto a quien conozca un dibujo que bajo el título de Salto mortal había realizado Alfred Kubin justo un siglo antes. Fue éste, como ya hemos dicho, un destacado precursor del surrealismo, precisamente por aportar al simbolismo, movimiento al que por cronología se le ha de adscribir, un carácter más vinculado con las teorías freudianas. En esta obra muestra a un hombre precipitándose hacia el sexo de una mujer ${ }^{13}$, eso sí, en este caso no sabemos si es el hombre el minúsculo o la mujer la gigante, cuestión que, por otro lado, resulta

\footnotetext{
10 Algunas películas a destacar en este sentido serían La inhumana, El golem o Metrópolis.

11 Una imagen parecida se dibuja en Átame (1990), en la famosa escena de la bañera en la que un submarinista de juguete se encalla en la vagina de una agradecida Victoria Abril.

12 SEGUIN, Jean-Claude. Pedro Almodóvar o la deriva de los cuerpos, Filmoteca Regional Francisco Rabal, Murcia, 2009, p. 142.

13 Resulta imposible no pensar al contemplar esta obra de Kubin en el famoso óleo de Gustave Courbet El origen del mundo (1866).
} 
irrelevante tanto para la lectura de la obra en sí como para su relación con el plano del filme de Almodóvar. Tal imagen del hombre empequeñecido ante una figura femenina de proporciones gigantescas también nos recuerda, aunque de una manera mucho menos directa que la pergeñada por Kubin, a una obra de René Magritte titulada, precisamente, La giganta $(1931)^{14}$.

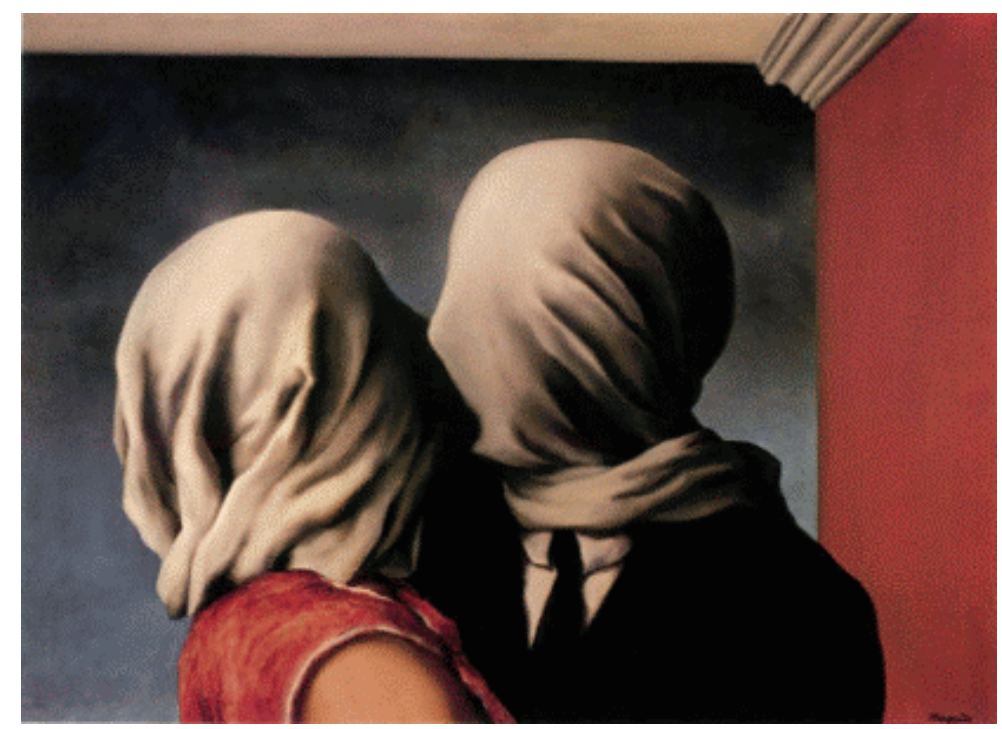

Los amantes (R. Magritte, 1928)

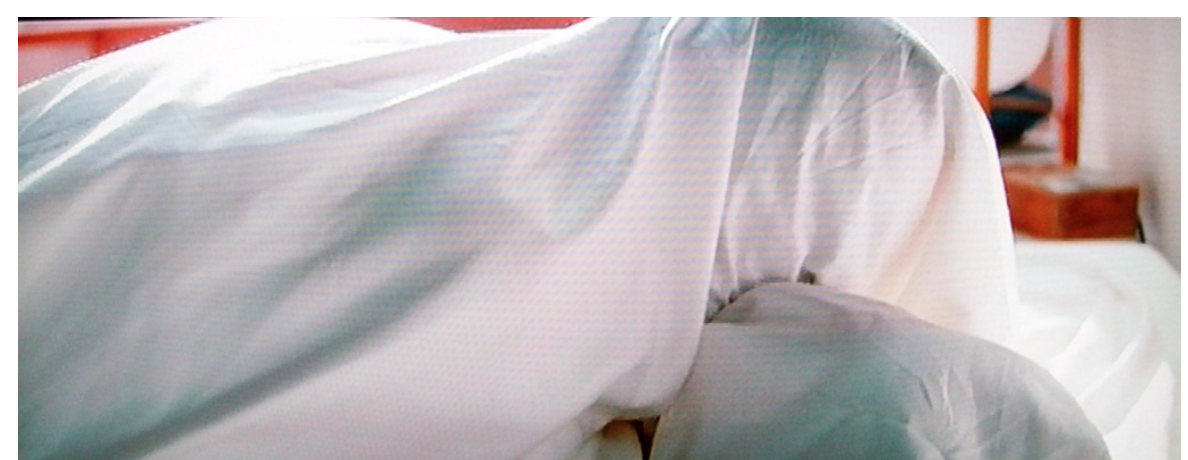

Los abrazos rotos (P. Almodóvar, 2009)

Quizá el caso más evidente lo constituya una imagen correspondiente a Los abrazos rotos $(2009)^{15}$. Dicho plano forma parte de una escena amorosa en la que el personaje protagonista, interpretado por Penélope Cruz, retoza en la cama con su esposo, un millonario mucho mayor que ella interpretado por José Luis Gómez. La portentosa luz del Mediterráneo inunda la estancia y su lecho. Ambos aparecen completamente cubiertos

14 Esta obra también podría considerarse, en cierto modo, deudora del cine en cuanto a la visión inclinada que se ofrece, propia de un contrapicado cinematográfico; de hecho, Borau la menciona como ejemplo de ello. Véase BORAU, José Luis, Ob. Cit., p. 99.

15 Aunque no atienda directamente a los referentes pictóricos manejados por Almodóvar, merece la pena destacar el análisis formal y plástico sobre esta película realizado en CASTRO DE PAZ, José Luis. "Sangre, fetiche, ceguera: deseos y abrazos rotos", Fotocinema, n 5, 2012, pp. 24-40. 
por las sábanas y, aun así, se siguen besando apasionadamente a través de las telas blancas. Qué duda cabe de que éste es uno de los momentos más inspirados de un filme que no está a la altura de otros títulos del cineasta ${ }^{16}$. En efecto, nos hallamos ante una certera referencia artística a la pintura surrealista, pues al espectador más avezado le resulta fácil, al ver dicha imagen, pensar en una de las obras más conocidas del prolífico Magritte: Los amantes (1928). Cierto es que son dos los cuadros del autor que responden al mismo título, ambos muy parecidos y protagonizados por una pareja cuyos rostros aparecen cubiertos por telas blancas. Aquí, claro está, nos referimos a aquel en el que la pareja se está besando. Dicha pintura de Magritte está llena de misterio y encanto, y es una de esas obras maestras que con muy pocos elementos es capaz de plantear infinidad de preguntas al espectador que la contempla.

Quien haya visto la película de Almodóvar y recuerde en qué deviene la historia de amor de los protagonistas de esta escena, podrá constatar que la elección por parte del director manchego de este cuadro surrealista como referente iconográfico no es ni casual ni caprichosa.

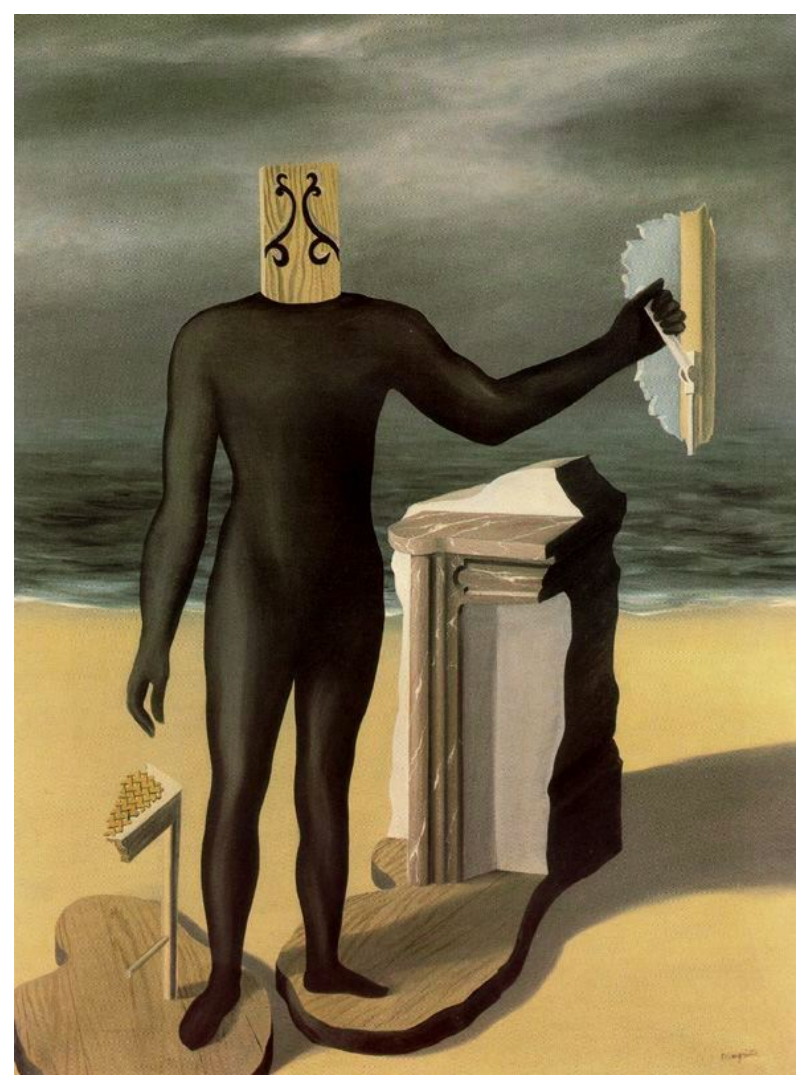

El hombre del mar (R. Magritte, 1927)
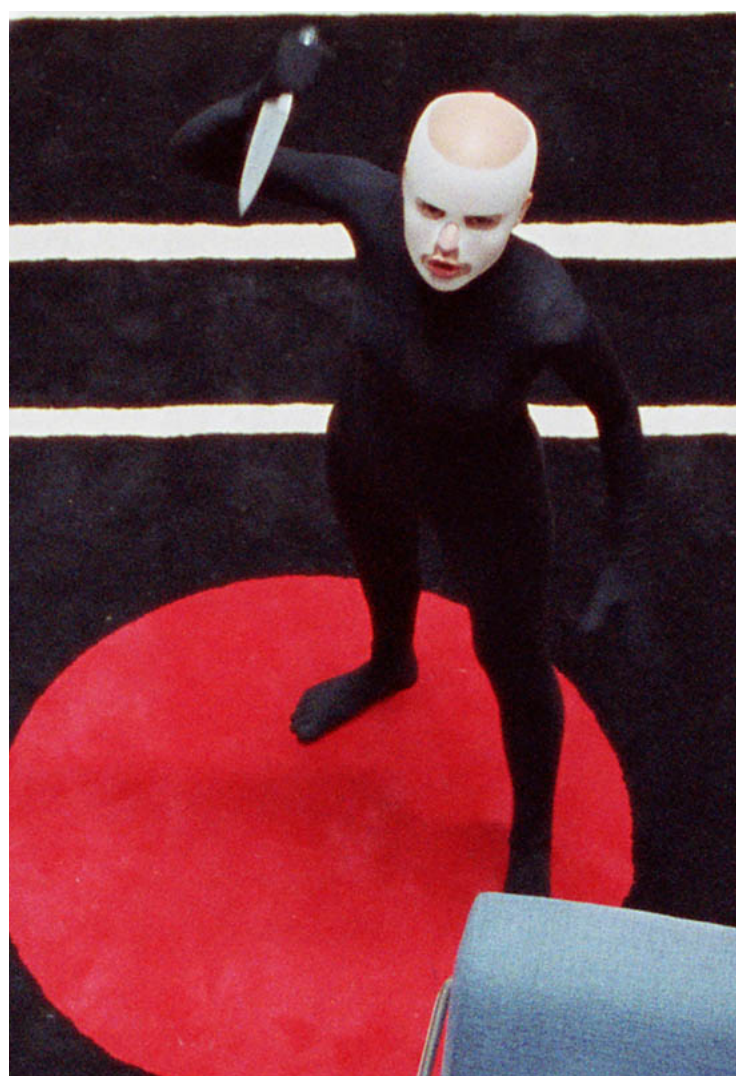

La piel que habito (P. Almodóvar, 2011)

16 Tampoco lo están, entre sus últimas creaciones, La mala educación (2004) o La piel que habito (2011) lo que no impide que en ambas películas se den ciertos destellos -sobre todo a lo que a la puesta en escena se refiere- propios de quien es, sin duda, una gran cineasta. 
Entre los años 1913 y 1914, el cineasta francés Lovis Fevillade llevó a la gran pantalla cinco historias protagonizadas por Fantômas, famoso personaje literario creado por Marcel Allain y Pierre Souvestre en 1911, y que llegó a convertirse en un auténtico fenómeno editorial al protagonizar más de una treintena de títulos. Se trataba de un criminal tan implacable como fascinante, un temible sociópata que empleaba múltiples identidades para perpetrar sus crímenes. Los cinco filmes dirigidos por Fevillade constituyeron la primera serie cinematográfica cuyo personaje principal no era un héroe sino un villano, convirtiéndose en todo un hito en la historia del cine policiaco ${ }^{17}$. La popularidad del personaje novelesco se incrementó, aún más si cabe, a partir de su llegada al cine, como demuestran las variadas versiones que se realizaron a lo largo del siglo tanto en este medio como en televisión o en novela gráfica. Poco después, entre 1905 y 1916, el cineasta francés emprendió el rodaje de otro ambicioso serial titulado Los vampiros (Les vampires) ${ }^{18}$.

A mediados de la década de los veinte, Magritte realizó algunos cuadros que, sin duda, nos remiten a los ya míticos filmes de Feuillade. Dos de ellos, titulados El hombre del mar y La ladrona, se nos revelan como certeras trasposiciones al lienzo de la iconografía de la que dotó el realizador galo a los criminales que protagonizaban sus seriales cinematográficos, tanto Fantômas como Los vampiros. Ambas pinturas de Magritte están protagonizadas por un único personaje, el cual, vestido de escrupuloso negro, oculta su rostro, ya sea sustituyendo éste por una tablilla de madera decorada como si de un violín se tratase, caso de El hombre del mar, o bien ocultándolo bajo una tupida capucha que sirve de continuación de la propia indumentaria, lo que sucede en La ladrona. El resultado, en ambos casos, es el de una suerte de sombra corpórea, una figura misteriosa y fantasmal, embutida en su malla negra y con el rostro oculto, al igual que solían presentarse en los seriales de Feuillade tanto el archivillano Fantômas y sus secuaces como la perversa Irma Vep -a veces su rostro quedaba a la vista, para lucimiento de Musidora, la actriz que la interpretaba- y sus compinches de la organización criminal. Hablamos, en este caso, de una iconografía concreta forjada en el celuloide ${ }^{19}$, gracias a Fevillade, y que termina pasando al ámbito de la pintura de la mano de Magritte ${ }^{20}$.

Pues tanto la atlética y sugerente figura de la Irma Vep de Fevillade, en cuanto que imagen cinematográfica, como el enigmático personaje de El hombre del mar, en cuanto que imagen pictórica, podrían considerarse referentes para Almodóvar a la hora de concebir al personaje protagonista de La piel que habito $(2011)^{21}$. En efecto, Elena Anaya

\footnotetext{
17 A comienzos de la década de los veinte, en Alemania, Fritz Lang llevaría a la gran pantalla las peripecias de otro gran criminal consagrado por el cine silente, el doctor Mabuse.

18 Véase GERHOLD, Hans. "El lirismo casual de la serie y de los precursores del cine policiaco: de The Adventures of Dolly [Las aventuras de Dolly] (1908) a Les vampires [Los vampiros] (1915-1916)" en VV.AA., FAULSTICH, Werner Y KORTE, Helmut (compiladores). Cien años de cine (1895-1995). Vol.1.(1895-1924). Desde los orígenes hasta su establecimiento como medio, Siglo XXI, México D.F., 1998, pp. 208-228.

19 A dicha iconografía también contribuirá, apenas un lustro después de los seriales de Fevillade, el inolvidable sonámbulo de Caligari, Césare, quien también embutido en una malla negra -eso sí, con el rostro al descubierto- materializará las pulsiones criminales de su funesto amo.

20 Véase SALAS GONZÁlEZ, Carlos. "Sombras amenazantes y personajes-sombra. Del cine a la pintura", Imafronte, $\mathrm{n}^{\circ}$ 21-22, Universidad de Murcia, 2011 , pp. 339-347.

21 Un acercamiento a la notable presencia de lo pictórico en este filme se da en THIBAUDEAU, Pascale. "EI cuerpo, la piel y la pantalla: los territorios habitados por Pedro Almodóvar", Fotocinema, n 7, 2013, pp. 192-208.
} 
actúa en una de las escenas más destacadas del filme enfundada en una malla negra que cubre la totalidad de su cuerpo, con la única excepción del rostro, que, no obstante, aparece oculto tras una máscara, lo que termina de conferir al personaje un halo de misterio y extrañeza íntimamente ligado al profundo secreto que custodia. Tan particular atuendo y tan destacada carga enigmática colocan al personaje almodovariano en estrecha relación con la mencionada pintura de Magritte, y por extensión, con otro personaje cinematográfico, perteneciente éste a aquel antiguo serial silente pergeñado por Fevillade.

\section{Dalí}

Sin abandonar La piel que habito hallamos otra curiosa imagen con importantes connotaciones surrealistas. Un hombre ridículamente disfrazado de tigre ataca a una mujer. Se trata del hijo prófugo de Marilia (Marisa Paredes), la empleada del doctor Ledgard (Antonio Banderas) ${ }^{22}$. La chica es Vera (Elena Anaya), protagonista femenina de la que ya hemos hablado en el apartado anterior. En esta ocasión, la malla que enfunda su cuerpo no es negra sino del color de la piel, dando la impresión de desnudez. El hombre vestido de felino no duda en atacarla con fiereza para lograr poseerla ${ }^{23}$.

Cómo transcurre y finaliza la escena no es asunto que aquí nos preocupe. Sí lo es la extraña imagen del tigre atacando a la mujer desnuda. Y es aquí donde vuelve a entrar en juego la pintura surrealista. Recordemos un pequeño lienzo al que Dalí bautizó como Sueño causado por el vuelo de una abeja alrededor de una granada un segundo antes de despertar (1944). Curiosamente, en tan kilométrico enunciado no se mencionan los dos elementos que protagonizan la escena: un fiero tigre -en realidad son dos- y una mujer desnuda. En efecto, es un tigre el que emerge de la boca de otro, que a su vez surge de la de un pez, que en última instancia nace de una gigantesca granada. Pero es ese último tigre el que nos interesa, pues se abalanza sobre una mujer desnuda-cómo no, Gala- que a modo de Venus descansa en la parte inferior del cuadro. La escena del ataque sexual del hombre-tigre almodovariano acontece, además, bajo una enorme reproducción de Venus recreándose con el Amor y la Música ${ }^{24}$. Y es que, de hecho, las citas textuales a otros artistas y cineastas son especialmente abundantes en esta película: Louis Bourgeois, Georges Franju, Pérez Villalta, el propio Tiziano... No obstante, Almodóvar lo considera más un robo ${ }^{25}$ que un homenaje o cita: "Cuando una película sale en una película mía no

\footnotetext{
Y en NAVARRETE-GALIANO, Ramón. "La piel que habito: nueva creación literaria, pictórica y escultórica de Almodóvar" en CRESPO FAJARDO, José L. (Coord.). Arte y cultura digital. Planteamientos para una nueva era, Eumed, Málaga, 2012, pp. 74-86.

22 Es curioso y relevante lo que el propio Almodóvar opina sobre dicho personaje cuando explica que para él la piel es como el lienzo para el pintor, véase DUNCAN, Paul y PEIRÓ, Bárbara (dir.). Les archives Pedro Almodóvar, Taschen, Cologne, 2011.

23 Es inevitable recordar al masoquista cubierto por una piel de tigre que encarrna Marcello Mastroianni en ¿Qué? (Che?, 1972), brillante delirio filmado por Roman Polanski en la Costa Amalfitana.

24 Tiziano vuelve a estar presente en un filme de Almodóvar -ya lo estuvo en Carne trémula (1997)- y esta vez por partida doble, ya que al mencionado cuadro del Prado le acompaña otro de los Uffizi: la famosa Venus de Urbino.

25 Véase HERRERA, Javier. "Almodóvar's Stolen Images" en D’LUGO, Marvin y VERNON, Kathleen M. (Eds.). A Companion to Pedro Almodóvar, Wiley-Blackwell, Pondicherry, 2013, pp. 345-363.
} 
es un homenaje, es un robo. Lo robo y hago que forme parte de la historia que he escrito, por eso funciona de un modo activo, mientras que un homenaje siempre responde a una cosa pasiva" 26 . Exactamente lo mismo que afirma sobre cineastas y películas se puede aplicar a artistas plásticos y pinturas. En cualquier caso, es una referencia menos explícita a Dalí la que aquí nos concita. En efecto, la pesadilla daliniana del tigre precipitándose sobre la mujer desnuda parece tener un reflejo kitsch y posmoderno en el filme de Almodóvar. Y para apuntalar dicha tesis sería conveniente recordar un curioso detalle sin importancia aparente: la difunta mujer del doctor Ledgard, con la que ha confundido el hombre-tigre a su víctima, responde precisamente al nombre de Gala.

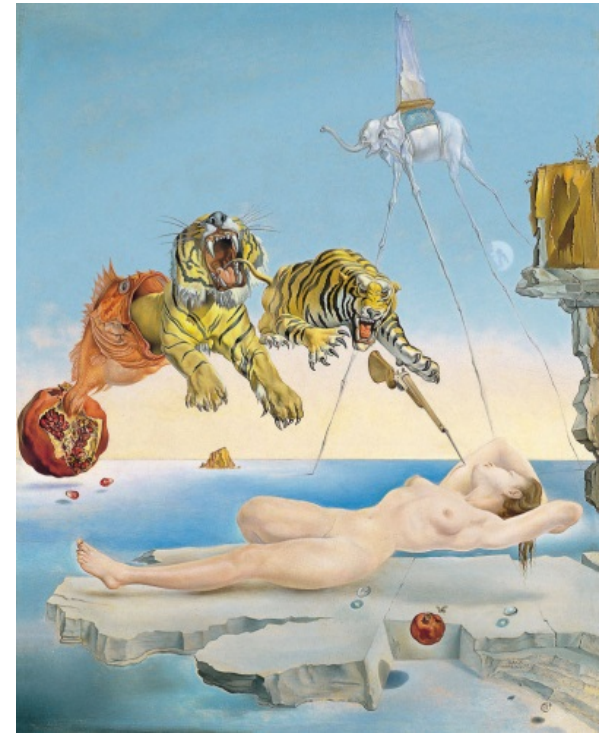

Sueño causado... (S. Dalí, 1944)

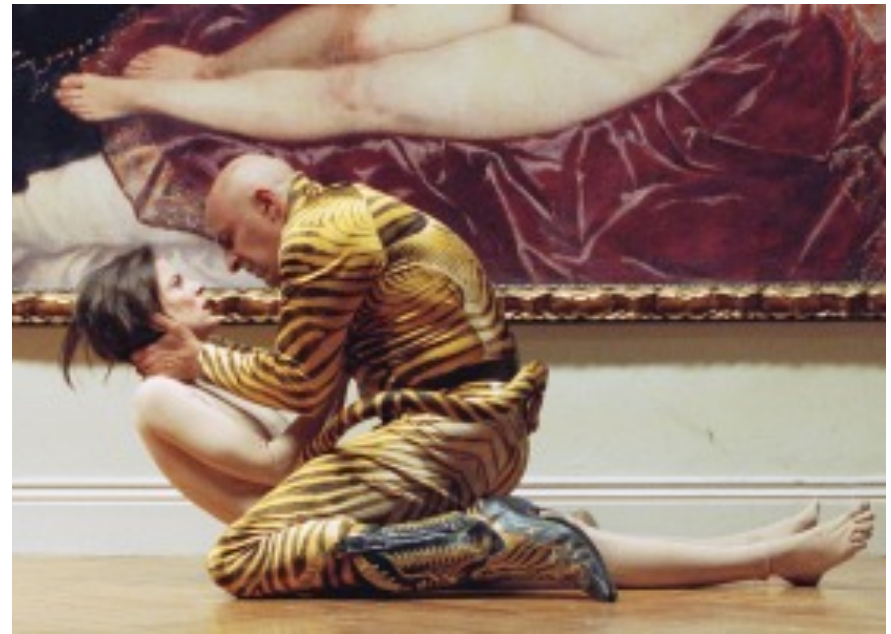

La piel que habito (P. Almodóvar, 2011)

\section{Conclusión}

No ha sido otro el propósito de este breve trabajo que el de seguir escrutando ese desbordante museo proyectado que es el cine de Almodóvar. A las abundantes citas artísticas relacionadas tanto con el arte tradicional como con algunos de los movimientos más rompedores del arte contemporáneo hemos querido añadir otra fuente iconográfica de sorprendente relevancia en algunas de sus películas, como es la que constituye la pintura surrealista. En este sentido, las referencias a ciertas obras de Magritte, Dalí o Kubin se nos han revelado como extraordinariamente eficaces y sutiles. El hecho de componer determinados planos inspirándose libremente en aquellas pinturas sólo se puede interpretar como un ejercicio de guiños a los espectadores más avezados, aquellos que cuentan con un mayor bagaje cultural y artístico. La mirada cómplice que el cineasta establece con este sector de su público se nos antoja un fenómeno digno de ser subrayado y valorado, contándose entre los indiscutibles aciertos de uno de los directores más controvertidos, polémicos e irregulares de las últimas décadas.

26 STRAUSS, Frédéric. Pedro Almodóvar. Un cine visceral, El País Aguilar, Madrid, 1995, p. 65. 